\title{
Hubungan Kadar Interferon Gamma (IFN- $\psi$ ) Pada Cairan Asites Dan Darah Dengan Grade Karsinoma Ovarium
}

\author{
Sakina Nasir Bagis ${ }^{1}$, Moh Nailul Fahmi², Hanggoro Tri Rinonce ${ }^{3}$ \\ ${ }^{1}$ Mahasiswa Program Sarjana Pendidikan Dokter, Fakultas Kedokteran, Kesehatan Masyarakat dan Keperawatan, UGM \\ ${ }^{2}$ Departemen Obstetri dan Ginekologi Fakultas Kedokteran, Kesehatan Masyarakat dan Keperawatan, UGM \\ ${ }^{3}$ Departemen Patologi Anatomi Fakultas Kedokteran, Kesehatan Masyarakat dan Keperawatan, UGM \\ Korespondensi: sakinabagis15@gmail.com
}

Submisi: 15 Maret 2019; Revisi: 27 Mei 2019; Penerimaan: 29 Mei 2019

\begin{abstract}
Background: Grading is one of prognostic factors of Ovarian carcinoma. The role of IFN- $\gamma$ in pathogesis of ovarian carcinoma is still controversial, it has anti-tumour and pro-tumour effects. Research on IFN-p levels and its relationship with grading of ovarian carcinoma has not been widely performed, even more in ascites and blood

Objective: To determine the relationships of interferon gamma levels (IFN- $\gamma$ ) with WHO grading of ovarian carcinoma in ascites and serum.

Method: we conducted a cross sectional study of 18 ovarian carcinoma patients underwent primary surgery. The pretreatment IFN- $\gamma$ levels in ascites and serum were quantified using ELISA, and correlation with WHO grading was analysed. Results and Discussion: The means of IFN- $\gamma$ levels either in ascites or serum of high grade group were higher than low grade group (in ascites $0.68 \mathrm{pg} / \mathrm{ml}$ vs $0.57 \mathrm{pg} / \mathrm{ml}$, in serum $0.84 \mathrm{pg} / \mathrm{m} / \mathrm{vs} 0.74 \mathrm{pg} / \mathrm{ml}$ ). However the mean of difference was not statistically significant (ascites, $p=0.780$; serum, $p=0.861$ ). As similar, there was no statistically different of IFN- $v$ levels in ascites $(0.66 \mathrm{pg} / \mathrm{ml})$ and serum $(0.81 \mathrm{pg} / \mathrm{ml}), p=0.568$.

Conclusion: There was no significant correlation between interferon-gamma (IFN- $\gamma$ ) levels and WHO grading either in ascites or serum ovarian carcinoma patients. There was no significant difference of IFN- $\gamma$ levels in ascites and serum.
\end{abstract}

Keywords: ascites; serum; grade; interferon gamma (IFN- - ); ovarian carcinoma

\section{ABSTRAK}

Latar Belakang: Grade merupakan salah satu faktor prognostik karsinoma. Peran IFN- $\gamma$ dalam pathogenesis karsinoma ovarium masih kontroversial. IFN- $\gamma$ memiliki efek anti-tumor dan juga pro-tumor. Penelitian tentang kadar IFN- $\gamma$ pada asites dan darah serta hubungannya dengan grade belum banyak dilakukan.

Tujuan: Mengetahui hubungan kadar interferon gamma (IFN- $\gamma$ ) dengan grade karsinoma ovarium pada cairan asites dan darah.

Metode: Penelitian ini menggunakan metode potong lintang pada 18 pasien karsinoma ovarium yang dilakukan operasi primer di RSUP Dr. Sardjito.

Hasil dan Pembahasan: Kadar rata-rata IFN- $\gamma$ pada cairan asites pada kelompok high grade sebesar 0,68 pg/ml, lebih tinggi dibandingkan dengan kelompok low grade sebesar $0,57 \mathrm{pg} / \mathrm{ml}$. Demikian juga pada serum, kadar rata-rata IFN- $\gamma$ pada kelompok high grade lebih tinggi dibandingkan dengan kelompok low grade yaitu 0,84 pg/ml vs $0,74 \mathrm{pg} / \mathrm{ml}$. Namun perbedaan rata-rata tersebut tidak signifikan secara statistik (asites, $p=0,780$; serum, $p=0,861$ ). Kadar rata-rata IFN- $\gamma$ pada cairan asites sebesar $0,66 \mathrm{pg} / \mathrm{ml}$, sedangkan pada darah sebesar $0,81 \mathrm{pg} / \mathrm{ml}$, namun perbedaan rata-rata tersebut tidak signifikan $(p=0,568)$.

Kesimpulan: Tidak terdapat perbedaan rata-rata yang signifikan antara kadar interferon-gamma (IFN- $\gamma$ ) pada karsinoma ovarium low grade dengan high grade baik pada cairan asites maupun serum. Tidak terdapat perbedaan rata-rata yang signifikan antara kadar interferon-gamma (IFN- $\gamma$ ) pada cairan asites dan serum pasien karsinoma ovarium.

Kata Kunci: asites; darah; grade; interferon gamma (IFN- $\gamma$ ); karsinoma ovarium 


\section{PENDAHULUAN}

Kanker ovarium merupakan kanker paling umum ke-7 dan penyebab kematian akibat kanker ke-8 pada wanita di dunia. ${ }^{1}$ Tingkat kematian yang tinggi ini disebabkan karena tidak adanya tanda patognomonis sehingga kebanyakan pasien datang sudah pada stadium lanjut. Di Indonesia, dari 92.200 kematian yang disebabkan oleh kanker pada wanita, kanker ovarium menempati urutan ke-4 dengan 7.6\% kasus, setelah kanker payudara, kanker serviks dan kanker kolorektal. ${ }^{2}$ Kanker ovarium banyak ditemukan pada wanita usia lanjut, sekitar setengah dari wanita yang didiagnosis memiliki kanker ovarium berusia lebih dari 63 tahun. Kanker ovarium memiliki prognosis yang semakin buruk apabila terdiagnosis pada stadium lanjut, 5-year-survival-rate pada stadium 1 sebesar $90 \%$, stadium 2 sebesar 70\%, stadium 3 sebesar 39\%, dan stadium 4 sebesar $14 \%{ }^{1}$

Kanker ovarium dapat dibedakan menjadi 3 tipe, yaitu tipe epitelium, sel germinal, dan sex cord-stromal. Tipe epitelium memiliki prevalensi tertinggi yaitu sebanyak $90 \%$, diikuti oleh tipe sel germinal sebanyak $3 \%$, dan sex cord-stromal sebanyak $2 \% 1$. Kanker ovarium tipe epitel memiliki beberapa subtipe histologis yaitu serosa, musinosa, endometrioid, sel jernih, Brenner, seromusin, dan undifferentiated. ${ }^{3}$

Kanker ovarium dapat diklasifikasikan menggunakan kriteria dari International Federation of Gynecology and Obstetrics (FIGO) yang terdiri dari 4 stadium. Selain itu, kanker ovarium juga dapat diklasifikasikan berdasarkan grade yang menunjukkan seberapa abnormal sel dan jaringan kanker yang terlihat di bawah mikroskop. Grade terdiri dari 3 golongan dan menjadi penting karena kanker dengan sel yang tampak lebih abnormal cenderung tumbuh dan menyebar lebih cepat, sehingga kemungkinan prognosisnya juga lebih buruk. ${ }^{4}$

Apabila seseorang yang menderita kanker ovarium sudah berada pada stadium lanjut, akan sering dijumpai manifestasi klinik berupa asites. Pasien dengan asites biasanya mengeluhkan rasa tidak nyaman karena adanya distensi abdomen, sulit untuk bergerak, kelelahan dalam beraktivitas, dan adanya gangguan dalam sistem pencernaan. Asites dapat berisi sel-sel tumor serta komponen seluler dari sistem kekebalan tubuh seperti limfosit, dan faktor regulasi seperti sitokin dan kemokin. Oleh karena itu, asites pada pasien kanker ovarium merupakan bahan yang ideal untuk mengevaluasi interaksi antara sistem imun host dan sel kanker di lingkungan mikro tumor. $^{5}$

Salah satu sitokin yang dapat ditemukan pada cairan asites kanker ovarium adalah IFN- $\gamma$. IFN- $\gamma$ terutama diproduksi oleh sel natural killer (NK) dan limfosit T CD8 ${ }^{+}$ (LTS) sitotoksik spesifik tumor. ${ }^{6}$ Dari berbagai referensi, dikemukakan bahwa IFN- $\gamma$ dapat menunjukkan aktivitas antitumor dan protumor. Dalam kedua kondisi baik antitumor maupun protumor, IFN- $\gamma$ mempengaruhi sel tumor secara langsung, serta pengembangan, rekrutmen, dan/atau aktivasi sel respon imun. Efek antitumor berupa penghambatan langsung pertumbuhan sel tumor serta pengenalan dan penghapusan sel-sel tumor oleh selsel respon imun. Di sisi lain, fungsi protumor IFN- $\gamma$ melibatkan sinyal antiapoptotic dan antiapoptotic, serta lolosnya sel tumor dari pengenalan dan sitolisis oleh LTS dan sel NK. Sifat yang pada akhirnya ditampilkan oleh IFN- $\gamma$ mungkin tergantung pada konteks spesifisitas tumor, faktor lingkungan mikro, dan intensitas sinyal. ${ }^{7}$

Tingkat IFN- $\gamma$ yang lebih tinggi yang terdeteksi dalam asites dikaitkan dengan parameter klinikopatologis yang lebih buruk seperti tingkat histologis yang tinggi dan status pembedahan yang kurang optimal. Terdapat peningkatan kadar IFN- $\gamma$ pada tumor dengan tingkat histologis yang tinggi. ${ }^{5}$

Penelitian tentang kadar IFN- $\nu$ dalam asites dan darah belum banyak dilakukan, sehingga penelitian ini perlu dilakukan untuk mengetahui kadar IFN- $\gamma$ pada asites dan darah sebagai faktor prognostik karsinoma ovarium serta hubungannya dengan grade dan juga perbandingan kadar IFN- $\gamma$ pada darah dan asites.

Tujuan penelitian ini yaitu mengetahui hubungan kadar interferon gamma (IFN- $\gamma$ ) dengan grade karsinoma ovarium pada cairan asites dan darah.

\section{METODE}

Desain penelitian yang digunakan pada penelitian ini adalah potong lintang (cross sectional). Populasi penelitian adalah pasien karsinoma ovarium yang ada di RSUP Dr. Sardjito Yogyakarta selama periode SeptemberDesember 2018.

Subjek penelitian ini adalah pasien yang menderita karsinoma ovarium dengan kriteria inklusi adalah penderita karsinoma ovarium yang menjalani operasi di RSUP Dr. Sardjito, bersedia menjadi subjek penelitian, asites dan darah dapat diambil. Kriteria ekslusi adalah memiliki riwayat keganasan lain selain kanker ovarium epitel, pernah menjalani operasi kanker ovarium sebelumnya, hamil dan menyusui. Berdasarkan periode dan kriteria penelitian didapatkan sebanyak 18 sampel asites dan 15 sampel darah.

Asites di ambil sebanyak $50 \mathrm{ml}$ saat tindakan pembedahan (pada stadium awal digunakan washing asites, pada stadium lanjut menggunakan asites murni). Siringe yang digunakan harus mengandung sejumlah heparin. Spesimen tersebut kemudian dipisahkan menjadi komponen supernatant dan komponen seluler dengan sentrifugasi 1200-1400 rpm selama 5 menit. Sedot supernatant dan simpan pada Eppendorf. Simpan tabung pada $-80^{\circ} \mathrm{C}$ sampai analisis. Untuk sampel berupa darah, darah diambil secara kolektif pada saat dilakukan pembedahan sebanyak $10 \mathrm{ml}$ intravena antecubitii. Darah dilakukan sentrifugasi $1200 \mathrm{rpm}$ selama 10 menit 
untuk didapatkan serumnya. Simpan didalam tabung pada suhu $-80^{\circ} \mathrm{C}$ sampai analisis. Pemeriksaan IFN- $\gamma$ menggunakan Human IFN- $\gamma$ (Interferon gamma) ELISA Kit (Fine Test, Wuhan, China). Cuci well (sumur) 2 kali sebelum menambahkan standar, sampel, dan kontrol. Standar atau sampel kemudian ditambahkan dan diinkubasi pada suhu $37^{\circ} \mathrm{C}$ selama 90 menit. Biotin-detection antibody working solution ditambahkan ke masing-masing sumur dan diinkubasi pada suhu $37^{\circ} \mathrm{C}$ selama 60 menit. Setelah dicuci 3 kali, larutan kerja SABC ditambahkan ke setiap sumur dan diinkubasi pada suhu $37^{\circ} \mathrm{C}$ selama 30 menit. Setelah dicuci 5 kali, substrat TMB ditambahkan dan diinkubasi pada suhu $37^{\circ} \mathrm{C}$ selama 15-30 menit. Stop solution kemudian ditambahkan dan dibaca pada $450 \mathrm{~nm}$ segera menggunakan microplate reader. Data dianalisis dengan Microsoft Excel.

\section{Analisis Statisik}

Semua analisis statistik dilakukan dengan menggunakan SPSS versi 21.0 (SPSS Inc., Chicago, IL). Kadar IFN- $\gamma$ yang diukur pada 18 asites dan 15 sampel serum menunjukkan distribusi normal. Dengan demikian, independent sample t-test digunakan untuk mengevaluasi perbedaan rata-rata antara kadar IFN- $\gamma$ dan grade. Signifikansi statistik, nilai $\mathrm{P}<0,05$ didefinisikan sebagai signifikan.

\section{HASIL DAN PEMBAHASAN}

Berdasarkan tabel 1, terdapat 18 subjek yang memenuhi kriteria inklusi dan eksklusi. Dari 18 subjek, sebagian besar memiliki IMT normal yaitu sebanyak 14 subjek $(77,8 \%)$ dan 4 subjek memiliki IMT overweight $(22,2 \%)$. Distribusi usia dibagi menjadi $<60$ tahun dengan 13 subjek $(72,2 \%)$ dan $\geq 60$ tahun dengan 5 subjek $(66,7 \%)$. Derajat histologis atau sering disebut grade dibagi menjadi derajat rendah/low grade dengan 4 subjek (22,2\%) dan derajat tinggi/high grade dengan 14 subjek $(77,8 \%)$. Untuk subtipe histopatologi, sebanyak 11 subjek $(61,1 \%)$ dengan subtipe serosa dan 7 subjek (38,9\%) dengan subtipe non-serosa. Terdapat 4 subjek $(22,2 \%)$ yang berada pada stadium awal dan 14 subjek $(77,8 \%)$ yang berada pada stadium lanjut. Pembedahan yang dilakukan secara suboptimal terdapat pada 11 subjek $(61,1 \%)$ dan secara optimal terdapat pada 7 subjek (38,9\%).

Tabel 1.

Karakteristik Subjek

\section{Variabel}

\section{IMT}

Normal

14

Berlebih/Overweight Jumlah

\section{Usia}

$<60$

$\geq 60$

Jumlah

\section{Grade}

Low-grade

High-grade

Jumlah
4

18

13

5

18

\section{4}

14

18

11

7

18

4

14

18

11

7

18
77,8 100

77,8

100

61,1

38,9

100

22,2

77,8 100

61,1

38,9

100 
Tabel 2.

Perbedaan kadar IFN- $\gamma$ low grade vs high grade pada cairan asites dan darah

\begin{tabular}{cccccc}
\hline & \multicolumn{3}{c}{$\begin{array}{c}\text { Kadar IFN- } \mathbf{~}(\mathbf{p g} / \\
\text { ml) }\end{array}$} & t & p \\
\cline { 2 - 6 } & $\mathbf{N}$ & Mean & SD & & \\
\hline $\begin{array}{c}\text { Grading Asites } \\
\text { Low-grade }\end{array}$ & 4 & 0,57 & 0,55 & & \\
$\quad$ High-grade & 14 & 0,68 & 0,68 & & \\
$\begin{array}{c}\text { Grading Serum } \\
\text { Low-grade }\end{array}$ & 4 & 0,74 & 0,56 & & \\
$\quad$ High-grade & 11 & 0,84 & 1,05 & & \\
Cairan Biologis & & & & $-0,551$ & 0,586 \\
$\quad$ Asites & 18 & 0,66 & 0,64 & & \\
$\quad$ Serum & 15 & 0,81 & 0,93 & & \\
\end{tabular}

Pada sampel asites, hasil yang terdapat pada tabel 2 menunjukkan adanya perbedaan rata-rata antara karsinoma ovarium low grade dan high grade. Rata-rata pada low grade sebesar $0,57 \mathrm{pg} / \mathrm{ml}$, sedangkan pada high grade sebesar 0,68 pg/ml. Dari hasil tersebut, rata-rata yang lebih tinggi ditemukan pada high grade. Namun, perbedaan rata-rata tersebut tidak bermakna secara statistik karena nilai signifikansi $p=0,780(p>0,05)$.

Pada sampel darah, juga didapatkan perbedaan ratarata antara low grade $(0,74 \mathrm{pg} / \mathrm{ml})$ dan high grade $(0,84$ $\mathrm{pg} / \mathrm{ml})$, dimana rata-rata yang lebih tinggi ditemukan pada high grade. Namun, perbedaan rata-rata tersebut tidak bermakna secara statistik karena nilai signifikansi $p=0,861(p>0,05)$.

Pada cairan asites dan darah, ditemukan perbedaan rata-rata antara keduanya. Rata-rata yang lebih tinggi didapatkan pada darah dengan hasil 0,81 pg/ml. Namun, perbedaan rata-rata tersebut tidak bermakna secara statistik karena nilai signifikansi $p=0,568(p>0,05)$.

Hasil analisis perbedaan rata-rata kadar IFN- $\gamma$ cairan asites pada low grade dan high grade didapatkan nilai signifikansi $p=0,780(p>0,05)$ yang membuktikan bahwa tidak terdapat perbedaan rata-rata yang bermakna antara kadar IFN- $\gamma$ asites pada low grade dan high grade. Apabila dilihat dari rata-rata masing-masing grading, menunjukkan bahwa rata-rata yang lebih tinggi ditemukan pada high grade, sehingga kadar IFN- $\gamma$ yang lebih tinggi mungkin berhubungan dengan grade yang lebih tinggi pada karsinoma ovarium. Studi mengenai IFN- $\gamma$ menunjukkan bahwa IFN dapat memberikan efek tertentu yang bersifat tumorigenesis. ${ }^{8}$ IFN- $\gamma$ melibatkan sinyal proliferatif dan antiapoptotik, serta melepaskan sel-sel tumor dari pengenalan dan sitolisis oleh LTS dan sel NK. ${ }^{7}$ IFN- $\gamma$ dapat memfasilitasi inisiasi tumor, lalu selanjutnya mempromosikan perubahan fenotip sel tumor menuju peningkatan kesiapan untuk pertumbuhan pada inang yang imunokompeten, selain itu IFN- $\gamma$ terlibat erat dalam beberapa mekanisme homeostatik atau mekanisme yang dipicu oleh kanker yang mempromosikan lingkungan mikro tumor yang imunosupresif. ${ }^{6}$ Hilangnya reseptor IFN- $\gamma$ juga dikaitkan dengan prognosis yang buruk pada kanker ovarium dan juga dilihat sebagai alasan yang mendasari terbatasnya keberhasilan dalam percobaan penggunaan terapi IFN- $\gamma$ pada kanker ovarium. ${ }^{9}$

Hasil penelitian ini sesuai dengan penelitian yang dilakukan sebelumnya oleh Chen et al., 2013 yang menyatakan bahwa terdapat peningkatan kadar IFN- $\gamma$ cairan asites yang signifikan dengan peningkatan grade karsinoma ovarium. Hal tersebut juga dibuktikan dengan hasil analisis statistik yang signifikan yang $p=0,04(p<0,05)$, sehingga peningkatan kadar IFN- $\gamma$ berhubungan dengan peningkatan grade karsinoma ovarium. Peningkatan kadar IFN- $\gamma$ juga berhubungan dengan stadium lanjut pada kanker ovarium, derajat histologi yang tinggi, dan pembedahan suboptimal. Peningkatan kadar IFN- $\gamma$ cairan asites juga dikaitkan dengan karakteristik klinikopatologis yang lebih buruk serta DFS dan OS yang lebih pendek. ${ }^{5}$

Hasil analisis perbedaan rata-rata kadar IFN- $\gamma$ cairan darah pada low grade dan high grade memiliki nilai signifikansi $p=0,861(p>0,05)$ yang menunjukkan bahwa tidak terdapat perbedaan rata-rata kadar IFN- $\gamma$ cairan darah yang bermakna antara low grade dan high grade. Apabila dilihat dari rata-rata masing-masing grading, menunjukkan bahwa rata-rata yang lebih tinggi ditemukan pada high grade, sehingga Kadar IFN- $\psi$ yang lebih tinggi mungkin berhubungan dengan grade yang lebih tinggi pada karsinoma ovarium. Hal ini mungkin sejalan dengan studi yang menyatakan efek protumor dari IFN- $\gamma$ seperti yang telah disebutkan diparagraf sebelumnya. Namun hasil analisis pada penelitian ini berbeda dengan yang dilakukan sebelumnya oleh Candido, et al., (2012), mereka mendapatkan hasil konsentrasi IFN- $\gamma$ pada serum kontrol lebih tinggi dibandingkan dengan pasien kanker ovarium dengan $p=0,151$, walaupun hasil tersebut tidak bermakna secara statistik. Mereka juga mendapatkan hasil konsentrasi IFN- $\gamma$ serum pada grade 2 lebih tinggi dibandingkan grade 3 dengan $p=0,246$, walaupun hasil tersebut tidak bermakna secara statistik. ${ }^{10}$ Penelitian sebelumnya yang mendeteksi kadar IFN- $\gamma$ pada darah atau serum belum banyak dilakukan, Nowak et al., (2010) dalam penelitiannya menyatakan sitokin tipe Th1 (termasuk IFN- $\gamma$ ) dalam serum hanya terdeteksi pada beberapa pasien, rendahnya konsentrasi sitokin ini (di bawah batas deteksi) dalam serum juga dicatat oleh peneliti lain. ${ }^{11}$

Perbedaan rata-rata kadar IFN- $\gamma$ pada cairan asites dan darah memiliki nilai signifikansi $p=0,568(p>0,05)$ yang menunjukkan bahwa tidak terdapat perbedaan rata-rata yang bermakna antara rata-rata kadar IFN- $\gamma$ pada cairan asites dan darah. Apabila dilihat rata-rata kadar IFN- $\gamma$ pada masing-masing cairan, hasil rata-rata pada darah memiliki nilai yang lebih tinggi dibandingkan dengan asites. Hal 
ini sejalan dengan penelitian Bamias et al., (2008) yang memperlihatkan nilai IFN- $\gamma$ lebih tinggi didapatkan pada cairan darah. ${ }^{12}$ Namun penelitian tersebut memiliki nilai signifikansi yang tinggi yaitu $p=0,802(p>0,05)$ sehingga tidak bermakna secara statistik, dan penelitian tersebut menggunakan nilai median bukan rata-rata. Studi lainnya menyatakan konsentrasi IFN- $\gamma$ yang lebih tinggi terdeteksi pada cairan intrakistik, dibandingkan pada darah dan jaringan tumor. ${ }^{10}$

\section{Keterbatasan Penelitian}

Keterbatasan dari penelitian ini yaitu terbatasnya jumlah sampel yang terkumpul, tidak semua sampel menggunakan cairan asites, dan kultur sel tidak dilakukan sehingga tidak mengetahui asal IFN- $\gamma$.

\section{KESIMPULAN DAN SARAN}

Tidak terdapat perbedaan rata-rata Kadar interferon-gamma (IFN- $\gamma$ ) cairan asites dan darah pada karsinoma ovarium dan high grade, sehingga hubungan Kadar interferon gamma terhadap grading tidak dapat dibuktikan. Tidak terdapat perbedaan rata-rata Kadar interferon-gamma (IFN- $\gamma$ ) pada cairan asites dan darah karsinoma ovarium.

Perlu dilakukan penelitian serupa dengan jumlah sampel yang lebih banyak, menggunakan cairan asites pada seluruh subjek penelitian, serta melakukan kultur sel sehingga dapat mengetahui asal IFN- $\gamma$.

\section{DAFTAR PUSTAKA}

1. American Cancer Society. 2018. Ovarian Cancer. Atlanta: American Cancer Society, Inc. 2018. Didapat dari https://www.cancer.org/cancer/ovarian-cancer/ about/key-statistics.html diakses 20 Mei 2018

2. World Health Organization. 2014. Cancer Country Profile: Indonesia. Didapat dari https://www.who. int/cancer/country-profiles/idn en.pdf diakses 28 Desember 2018

3. World Health Organization. 2014. WHO Classification of Tumors of Female Reproductive Organs. $4^{\text {th }}$ Edition. pp 15-40.

4. Cancer Research UK. 2017. Cancer Grading. Didapat dari https://www.cancerresearchuk.org/aboutcancer/what-is-cancer/cancer-grading diakses $20 \mathrm{Mei}$ 2018.
5. Chen, Y.L., Cheng, W.F., Chang, M.C., Lin, H.W., Huang, C.T., Chien, C.L. and Chen, C.A., 2013. Interferongamma in ascites could be a predictive biomarker of outcome in ovarian carcinoma. Gynecologic oncology, 131(1), pp.63-68.

6. Mojic, M., Takeda, K. and Hayakawa, Y., 2017. The dark side of IFN- - : its role in promoting cancer immunoevasion. International journal of molecular sciences, 19(1), p.89.

7. Zaidi, M.R. dan Merlino, G., 2011. The two faces of interferon- $\gamma$ in cancer. Clinical cancer research, 17(19), pp.6118-6124.

8. Castro, F., Cardoso, A.P., Gonçalves, R.M., Serre, K. and Oliveira, M.J., 2018. Interferon-gamma at the crossroads of tumor immune surveillance or evasion. Frontiers in immunology, 9, p.847.

9. Duncan, T.J., Rolland, P., Deen, S., Scott, I.V., Liu, D.T., Spendlove, I. and Durrant, L.G., 2007. Loss of IFN $\gamma$ receptor is an independent prognostic factor in ovarian cancer. Clinical cancer research, 13(14), pp.4139-4145.

10. Cândido, E.B., Silva, L.M., Carvalho, A.T., Lamaita, R.M., Filho, R.M.P., Cota, B.D.C.V. and Silva-Filho, A.L.D., 2013. Immune response evaluation through determination of type 1 , type 2 , and type 17 patterns in patients with epithelial ovarian cancer. Reproductive Sciences, 20(7), pp.828-837.

11. Nowak, M., Glowacka, E., Szpakowski, M., Szyllo, K., Malinowski,A., Kulig, A., Tchorzewski, H. and Wilczynski, J., 2010. Proinflammatory and immunosuppressive serum, ascites and cyst fluid cytokines in patients with early and advanced ovarian cancer and benign ovarian tumors. Neuroendocrinology Letters, 31(3), pp.375-383.

12. Bamias, A., Koutsoukou, V., Terpos, E., Tsiatas, M.L., Liakos, C., Tsitsilonis, O., Rodolakis, A., Voulgaris, Z., Vlahos, G., Papageorgiou, T. and Papatheodoridis, G., 2008. Correlation of NK T-like CD3+ CD56+ cells and $C D 4+C D 25+$ (hi) regulatory $T$ cells with VEGF and TNF $\alpha$ in ascites from advanced ovarian cancer: Association with platinum resistance and prognosis in patients receiving first-line, platinumbased chemotherapy. Gynecologic oncology, 108(2), pp.421-427. 